\title{
Differential Uptake, Distribution within Tissues, and Use Efficiency of Manganese, Iron, and Zinc by Olive Cultivars Kothreiki and Koroneiki
}

\author{
Theocharis Chatzistathis ${ }^{1}$ and Ioannis Therios \\ Laboratory of Pomology, School of Agriculture, Aristotle University, 54124, \\ Thessaloniki, Greece
}

\author{
Dimitrios Alifragis \\ Laboratory of Forest Soils, School of Forestry and Natural Environment, \\ Aristotle University, 54124, Thessaloniki, Greece
}

Additional index words. nutrient uptake, nutrient use efficiency, olive cultivar, parent material, marl, Gneiss schist., Peridotite

\begin{abstract}
Three-month-old rooted olive cuttings (Olea europaea L., cvs. Koroneiki and Kothreiki of $\approx 20$ to $25 \mathrm{~cm}$ in height) were grown outdoors for 140 days (from 30 May until 17 Oct.) under ambient conditions in black plastic bags containing $3 \mathrm{~kg}$ of soil. Three soils from different parent material (Marl, Gneiss schist., and Peridotite) and with different physicochemical properties were chosen. In all the soils, 'Kothreiki' produced significantly greater total plant biomass compared with 'Koroneiki'. Furthermore, between the two cultivars studied, 'Kothreiki' absorbed significantly greater quantity of manganese (Mn), iron ( $\mathrm{Fe})$, and zinc ( $\mathrm{Zn})$ per plant compared with 'Koroneiki'. In all the soils, significantly greater concentrations of $\mathrm{Mn}, \mathrm{Fe}$, and $\mathrm{Zn}$ were recorded in the root system of both cultivars compared with those of leaves and stems. Between the two cultivars studied, 'Kothreiki' had greater percentage of the total Mn content distributed in the root system $(74 \%$ to $80 \%)$ than 'Koroneiki' $(44 \%$ to $56 \%)$. That high ability of 'Kothreiki' to accumulate $\mathrm{Mn}$ in its root system could possibly be advantageous in soils with high Mn concentrations and could constitute a detoxification mechanism to olive trees, protecting the above-ground part of the tree from Mn toxicity. Furthermore, greater concentrations of magnesium $(\mathrm{Mg})$ were recorded in the root system of the olive plants than in leaves and stems, whereas potassium (K) and calcium (Ca) concentrations were greater in leaves compared with those of other tissues (roots and stems). The total per plant quantity of $\mathrm{Ca}, \mathrm{Mg}$, and $\mathrm{K}$ was significantly greater in the cultivar Kothreiki than 'Koroneiki' in all the soils tested. On the other hand, 'Kothreiki' presented significantly lower use efficiency of $\mathrm{Mn}$ in Marl and Gneiss schist soils, and that of Fe and Mg in all soils, so 'Koroneiki' could be considered as a Mn- and Fe-efficient olive cultivar, whereas 'Kothreiki' was Mn- and Fe-inefficient.
\end{abstract}

Differential uptake of a nutrient element by various plant species or cultivars has been referred to by many authors (Damon and Rengel, 2007; Jiang, 2008; Rengel and Damon, 2008; Shuxin et al., 2000). Furthermore, differential distribution, especially of micronutrients, between cultivars of the same plant species is of great importance in cases of micronutrient deficiencies and toxicities. In cases of micronutrient toxicity, it is important to choose genotypes with low uptake and transport from root to shoot of the specific element, like for example happens with manganese $(\mathrm{Mn})$ in $\mathrm{Mn}$ toxicity conditions. In that case, low transport of Mn from

\footnotetext{
Received for publication 14 July 2009. Accepted for publication 22 Sept. 2009.

We thank Mrs. Sofia Kouti and Mrs. Vasiliki Tsakiridou for their assistance in chemical analyses.

${ }^{1}$ To whom reprint requests should be addressed; e-mail ChChatzi@in.gr.
}

root to shoot, in many plant species, is the result of the oxidation of $\mathrm{Mn}^{2+}$ to $\mathrm{Mn}^{4+}$ (El Jaoual and Cox, 1998). In contrast to that, in cases of micronutrient deficiency, the chosen genotypes should have great uptake capacity and transport of the particular element from the root system to the leaves (Rengel, 2001). In addition to that, high internal nutrient use efficiency is also another property that one genotype should have under those conditions (Jiang, 2006; Jiang and Ireland, 2005).

For the olive tree, although it is considered a species with great capacity to survive and produce under low-fertility soils, almost nothing has been investigated so far about micronutrient absorption, distribution, and use efficiency as well as whether genotypic differences exist among olive cultivars concerning micronutrient absorption [especially $\mathrm{Mn}$, iron ( $\mathrm{Fe})$, and zinc $(\mathrm{Zn})]$ and nutrient use efficiency, which, for example, exist in some crop cultivars (Jiang, 2006, 2008; Rengel, 2001). For that purpose, two well-known, widely cultivated Greek olive cultivars
(Koroneiki as an oil-producing cultivar and 'Kothreiki' as a dual-purpose one) were used in this study. 'Koroneiki' is resistant to drought and winds, whereas 'Kothreiki' is very resistant to cold and it can be cultivated up to $800 \mathrm{~m}$ altitude (Therios, 2005).

The aim of the present investigation was to find possible genotypic differences between the two previously mentioned olive cultivars in the absorption, distribution among various tissues, and use efficiency of $\mathrm{Mn}, \mathrm{Fe}$, and $\mathrm{Zn}$ in each of the three soils used. To have a better and global view of the mineral nutrition of these two olive cultivars in the three soils used, we also studied the absorption, distribution, and use efficiency of the macronutrients calcium $(\mathrm{Ca})$, magnesium $(\mathrm{Mg})$, and potassium $(\mathrm{K})$. Three soils from different parent material (Marl, Gneiss schist., and Peridotite) and with different physicochemical properties were chosen as a medium for plant growth.

\section{Materials and Methods}

Plant material and soil sampling. Threemonth-old rooted olive cuttings (Olea europaea L., cvs. Koroneiki and Kothreiki $\approx 20$ to $25 \mathrm{~cm}$ in height) were grown outdoors for $140 \mathrm{~d}$ (from 30 May to 17 Oct.) under ambient conditions in black plastic bags containing $3 \mathrm{~kg}$ of soil. The plants of each cultivar were randomized and separated, based on their height and initial total fresh weight, in three similar groups (corresponding to the three soils used) and six replicates per cultivar and per soil type were included. The total number of plants was 36 (three soils $\times$ two cultivars $\times$ six replicates). Three soils, derived from different parent material (Marl, Gneiss schist., and Peridotite) and having different properties, were included in the study. The soils were collected around the city of Thessaloniki, i.e., Epanomi (Marl), Souroti (Gneiss schist.), and Galatista (Peridotite), and represent the three basic soil types on which olive tree is growing in the region of Thessaloniki, Macedonia, northern Greece. All these soils belong to the Entisols (Orthents) according to the Soil Taxonomy (1975) system. The soil samples were collected from the upper $60 \mathrm{~cm}$ of each soil, where most of the olive root system is usually growing. This soil layer of $60 \mathrm{~cm}$ included $A_{p}$ and $A_{c}$ horizons in the Marl soil, $A_{p}$ in the Gneiss schist., and $\mathrm{A}$ and $\mathrm{B}$ horizons in the Peridotite soil. During the period of experimentation, the plants were irrigated three times a week until the end of August and two times a week from the beginning of September to 17 Oct. with $200 \mathrm{~mL}$ of distilled water.

Soil sample analysis. After collection, soil samples were dried at room temperature, separated from stones, and sieved to pass a 10-mesh screen before analyses. General chemical analyses as well as extraction of micronutrients were conducted in each one of the three soils. General chemical analyses of the soils included the $\mathrm{pH}$ measurement; the percent content of organic matter; the 
Table 1. Physicochemical properties of the three soils (from parent material Marl, Gneiss schist., and Peridotite) (in each soil type six samples were included).

\begin{tabular}{|c|c|c|c|c|c|c|c|c|c|c|}
\hline & Sand & Clay & Loam & \multirow[b]{2}{*}{ Texture } & \multirow{2}{*}{$\begin{array}{c}\text { Organic matter } \\
(\%)\end{array}$} & \multirow[b]{2}{*}{$\mathrm{pH}$} & \multirow[b]{2}{*}{$\mathrm{CaCO}_{3}(\%)$} & Calcium & Magnesium & Potassium \\
\hline Soil/parent material & & $(\%)$ & & & & & & \multicolumn{3}{|c|}{ (mEq/100 g soil) } \\
\hline Marl & 62.4 & 14.8 & 22.8 & SCL & 2.88 & 7.63 & 3.5 & 36.90 & 2.25 & 1.4 \\
\hline Gneiss schist. & 68.4 & 20.8 & 10.8 & SL & 1.68 & 7.15 & 1.3 & 10.68 & 2.17 & 1.2 \\
\hline Peridotite & 52.4 & 26.8 & 20.8 & SCL & 4.44 & 7.97 & 15.4 & 36.21 & 2.46 & 6.7 \\
\hline
\end{tabular}

$\mathrm{SCL}=$ sandy clay loam; SL $=$ sandy loam.

exchangeable cations $\mathrm{Ca}, \mathrm{Mg}$, and $\mathrm{K}$; the particle size analysis; and the percent $\mathrm{CaCO}_{3}$. The $\mathrm{pH}$ was determined in soil with distilled water (solution 1:1) (Bates, 1964), the organic matter with the $\mathrm{K}_{2} \mathrm{Cr}_{2} \mathrm{O}_{7}$ method (Allison, 1965), the interchangeable cations according to the method of $\mathrm{CH}_{3} \mathrm{COONH}_{4}$ $\mathrm{pH} 9(\mathrm{pH} 9$ was chosen to reduce the solubilization of $\mathrm{CaCO}_{3}$ as the $\mathrm{pH}$ values of the three soils were above 7) (Alifragis and Papamichos, 1995; Bower et al., 1952), and the particle size analysis according to the 'Bouyoucos' method. According to Klute (1986), 'Bouyoucos' method provides generally good results for particle soil analysis. Finally, the percent $\mathrm{CaCO}_{3}$ content was determined with the calcium meter method, whereas the extraction of $\mathrm{Mn}, \mathrm{Fe}$, and $\mathrm{Zn}$ in the three soils was conducted with the DTPA method (Alifragis and Papamichos, 1995).

Plant growth parameters. Once the plants were harvested (at the 140th day), shoot length as well as fresh and dry weight of leaves, stems, roots, and total plant fresh and dry weights were measured. Samples were initially weighed (fresh weight), then washed with tap and afterward with distilled water, dried at $75^{\circ} \mathrm{C}$ for $24 \mathrm{~h}$, and weighed again (dry weight).

Manganese, iron, zinc, calcium, magnesium, and potassium concentrations in plant tissues. After the plants were separated into stems, roots, and leaves, they were washed once with tap and twice with distilled water, dried at $75{ }^{\circ} \mathrm{C}$ for $24 \mathrm{~h}$, and the organs were milled to a fine powder to pass a 30 mesh screen. A portion of $0.5 \mathrm{~g}$ of the fine powder of each sample was dry-ashed in a muffle furnace at $515{ }^{\circ} \mathrm{C}$ for $5 \mathrm{~h}$. Then, the ash was dissolved in $3 \mathrm{~mL}$ of $6 \mathrm{~N}$ hydrochloric acid and diluted with double distilled water up to $50 \mathrm{~mL}$ and the concentrations of the elements $\mathrm{Ca}, \mathrm{Mg}, \mathrm{K}, \mathrm{Mn}, \mathrm{Fe}$, and $\mathrm{Zn}$ were determined by atomic absorption spectroscopy (Perkin-Elmer 2340, Waltham, MA). The concentrations of the microelements were expressed in micrograms per gram dry weight (DW), whereas those of macronutrients in percent DW. Multiplying the concentration of each nutrient (micrograms or milligrams per gram DW) found in each plant part by its dry weight, the content (absolute quantity) of each nutrient per plant part at the end (at the 140th day) was calculated. By addition of the nutrient contents of different plant parts, total nutrient content (micrograms or milligrams) per plant and thus total nutrient uptake per plant was computed. Calculating for each olive cultivar, and for all soils, the absolute quantities of all nutrients in the different tissues (leaves, stem, and root) and by dividing with the corresponding, for each nutrient, total per plant quantity, the percent distribution of the nutrients in the three tissues (leaves, stem, and roots) is calculated. Finally, the nutrient use efficiency of each nutrient, which is defined as the amount of biomass produced per unit of nutrient, was further calculated (Chapin and Van Cleve, 1991).

Statistics. All data were statistically analyzed by using the SPSS software package (SPSS 8.0.1 for Windows, Chicago, IL) and, particularly, for comparison of means between the two olive cultivars in each one of the three soils, $t$ test was performed for $P \leq 0.05$.

\section{Results}

Soil properties. The physicochemical properties of the three soils are presented in Table 1. The soils from parent material Marl and Peridotite were sandy clay loam, whereas that from Gneiss schist. was sandy loam (SL). The $\mathrm{pH}$ of the soil from parent material Gneiss schist. was 7.15, whereas that of the other two soils (from parent material Marl and Peridotite) was 7.63 and 7.97 , respectively. The organic matter content $(\%)$ of the Gneiss schist. soil was relatively low, whereas that of the other two soils was sufficient and ranges between $2.88 \%$ and $4.44 \%$. The $\mathrm{CaCO}_{3}(\%)$ content was medium $(15.4 \%)$ in the Peridotite soil, whereas in the other two soils, it was very low. Among the exchangeable cations, $\mathrm{Ca}$ dominates in the Marl and Peridotite soils (which are saturated in $\mathrm{Ca}$ ), whereas in Gneiss schist., it was $\approx 27 \%$ of that in the other two soils. Potassium was more than five times greater in the Peridotite soil compared with the other two soils. The concentrations of $\mathrm{Mg}$ were approximately equal in the three soils (Table $1)$. The cation exchange capacity (CEC) values for the Marl, Gneiss schist., and Peridotite soils were $43 \%, 17 \%$, and $48 \%$, respectively, whereas the water-holding capacity values of the three studied soils were $29 \%$, $22 \%$, and $30 \%$ for the Marl, Gneiss schist., and Peridotite soils, respectively. From Table 2 it is evident that the greatest concentration of the DTPA-extractable Mn was recorded in the Peridotite soil, whereas in the other two soils, it was only $\approx 50 \%$ of that in the Peridotite soil. The concentration of $\mathrm{Fe}$ is 3 , 4 , and $5 \mathrm{mg} \cdot \mathrm{kg}^{-1}$ soil in Marl, Peridotite, and Gneiss schist. soil, respectively, whereas the concentrations of $\mathrm{Zn}$ were approximately equal in the three soils.

Plant growth parameters. Between the two cultivars and in all soils, 'Kothreiki' had significantly greater total plant biomass compared with 'Koroneiki'. Particularly, 'Kothreiki' had significantly greater fresh
Table 2. Manganese (Mn), iron (Fe), and zinc ( $\mathrm{Zn}$ ) concentration $\left(\mathrm{mg} \cdot \mathrm{kg}^{-1}\right.$ of soil) in the three soils after DTPA extraction.

\begin{tabular}{lccc}
\hline Soil/nutrient element & Mn & Fe & $\mathrm{Zn}$ \\
\hline Marl & 7 & 3 & 1.5 \\
Gneiss schist. & 6 & 5 & 1.5 \\
Peridotite & 12 & 4 & 1.0 \\
\hline
\end{tabular}

and dry weights of root and leaves compared with 'Koroneiki'. The fresh weight of the root system of 'Koroneiki' was $\approx 41 \%, 61 \%$, and $32 \%$ of that of cultivar Kothreiki in the Marl, Gneiss schist., and Peridotite soils, respectively (Table 3).

Concentrations of nutrient elements in plant tissues, total plant content of manganese, iron, zinc, calcium, magnesium, and potassium and nutrient use efficiency. 'Kothreiki' (in all soils) absorbed significantly greater quantities of $\mathrm{Mn}, \mathrm{Fe}$, and $\mathrm{Zn}$ compared with that absorbed by 'Koroneiki' (Fig. 1). In both olive cultivars and all soils used, greater concentrations of $\mathrm{Mn}, \mathrm{Fe}, \mathrm{Zn}$, and $\mathrm{Mg}$ were recorded in the root system than in leaves and stems, whereas greater concentrations of $\mathrm{K}$ and $\mathrm{Ca}$ were found in leaves than in the other tissues (root, stems) (Table 4). The total plant content of $\mathrm{Ca}, \mathrm{Mg}$, and $\mathrm{K}$ was also significantly greater in the cultivar Kothreiki than in 'Koroneiki' in all soils (Fig. 1).

From Table 5 it is concluded that in all soils, both olive cultivars had the greatest percentage of the total per plant Mn distributed in the root. 'Kothreiki' had in all soils a greater percentage $(74 \%$ to $81 \%)$ of the total per plant $\mathrm{Mn}$ distributed in the roots than 'Koroneiki' (44\% to 56\%). Concerning $\mathrm{Fe}$ distribution in root, stem, and leaves, more than $90 \%$ of the total per plant $\mathrm{Fe}$ was distributed in the root system and only $\approx 0.6 \%$ to $2.4 \%$ in leaves. Zinc, in all soils, was mainly distributed in the root system than in leaves and stem. 'Kothreiki' had greater distribution $(\%)$ of the total per plant $\mathrm{Zn}$ in the root system (and lower in the stems) than 'Koroneiki'. It is remarkable that although a much greater proportion of the total per plant content of $\mathrm{Mn}$ and $\mathrm{Zn}$ was recorded in the root system of 'Kothreiki' compared with that of 'Koroneiki', no significant differences were found in the percentage of the total per plant content of $\mathrm{Mn}$ and $\mathrm{Zn}$ distributed in the leaves of both cultivars. Calcium and $\mathrm{K}$ were generally equally distributed among the three vegetative tissues (root, stem, and leaves), in both olive cultivars and all soils, whereas $\mathrm{Mg}$ was mainly distributed in the root system (data not shown).

Table 6 shows the use efficiency of all nutrients for both olive cultivars and in all 
Table 3. Plant growth parameters of the olive cultivars Koroneiki and Kothreiki grown in three soils with different physicochemical properties.

\begin{tabular}{|c|c|c|c|c|c|c|c|c|c|c|c|}
\hline \multirow[b]{2}{*}{ Soil } & \multirow[b]{2}{*}{ Cultivar } & \multirow[b]{2}{*}{ Shoot length $(\mathrm{cm})$} & \multicolumn{2}{|c|}{ Root wt (g) } & \multicolumn{2}{|c|}{ Stems wt $(\mathrm{g})$} & \multicolumn{2}{|c|}{ Leaves wt (g) } & \multirow[b]{2}{*}{ Root/stem+ leaves } & \multicolumn{2}{|c|}{ Total plant wt (g) } \\
\hline & & & FW & DW & FW & DW & FW & DW & & FW & DW \\
\hline Marl & Koth & $117 \mathrm{a}$ & $82.65 \mathrm{a}$ & $16.02 \mathrm{a}$ & $25.22 \mathrm{a}$ & $13.34 \mathrm{a}$ & $22.39 \mathrm{a}$ & $10.80 \mathrm{a}$ & $1.72 \mathrm{a}$ & $130.26 \mathrm{a}$ & $40.17 \mathrm{a}$ \\
\hline \multirow[t]{2}{*}{ Peridotite } & Kor & $114 \mathrm{a}$ & $33.27 \mathrm{~b}$ & $9.58 \mathrm{~b}$ & $23.03 \mathrm{a}$ & $12.70 \mathrm{a}$ & $16.14 \mathrm{~b}$ & $7.37 \mathrm{~b}$ & $0.86 \mathrm{~b}$ & $72.44 \mathrm{~b}$ & $29.65 \mathrm{~b}$ \\
\hline & Koth & $123 \mathrm{a}$ & $103.31 \mathrm{a}$ & $20.19 \mathrm{a}$ & $25.95 \mathrm{a}$ & $13.90 \mathrm{a}$ & $21.62 \mathrm{a}$ & $10.36 \mathrm{a}$ & $2.17 \mathrm{a}$ & $150.88 \mathrm{a}$ & $44.46 \mathrm{a}$ \\
\hline
\end{tabular}

${ }^{z}$ The different letters in the same column symbolize statistically significant differences between the two cultivars in each of the three soils for $P \leq 0.05$ ( $\mathrm{n}=6$ ) (SPSS, Chicago, IL; $t$ test).

$\mathrm{FW}=$ fresh weight; DW = dry weight.

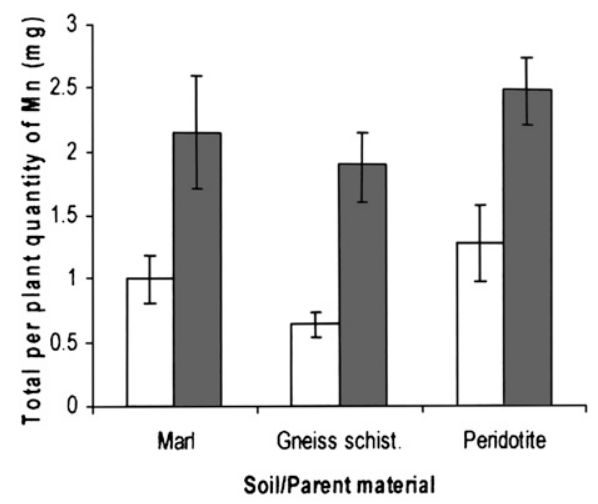

(A)

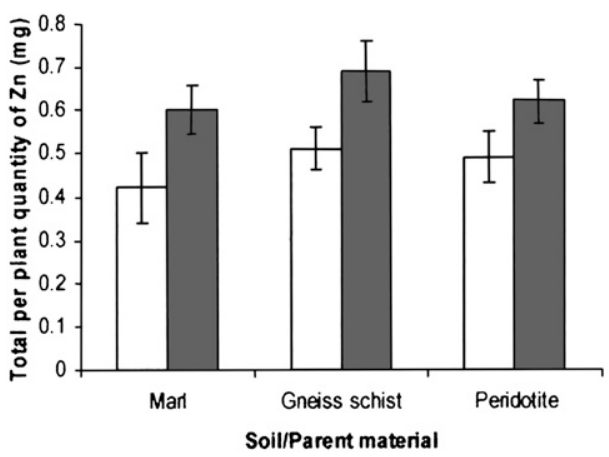

(C)

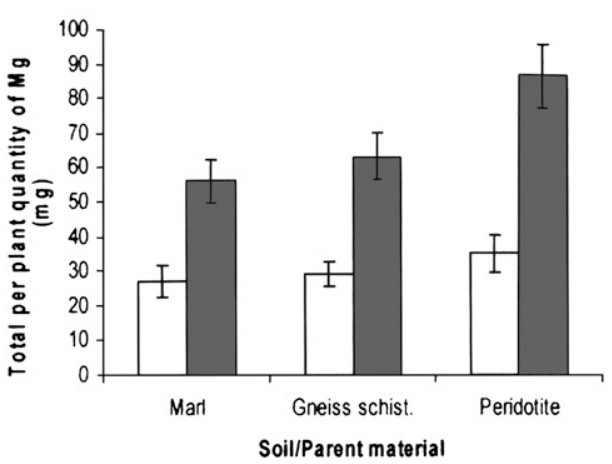

(E)

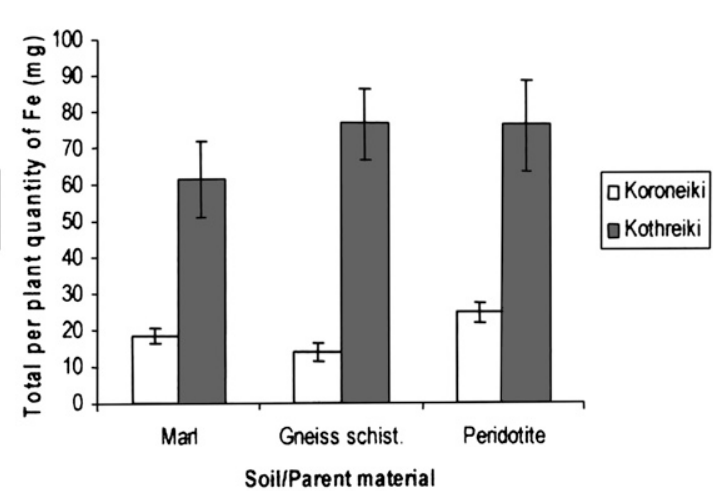

(B)

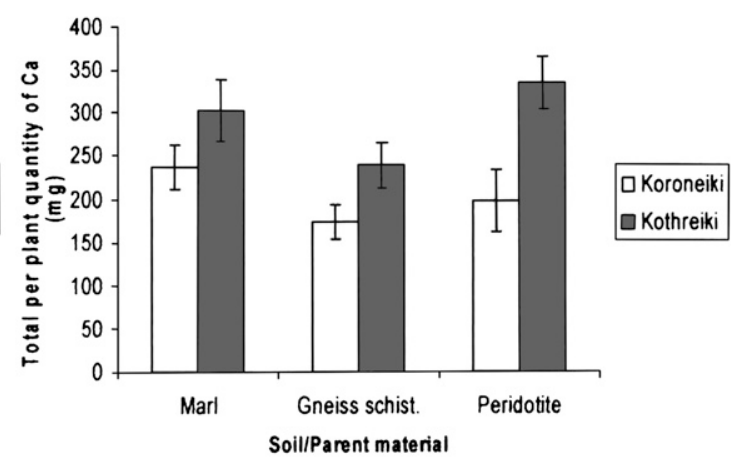

(D)

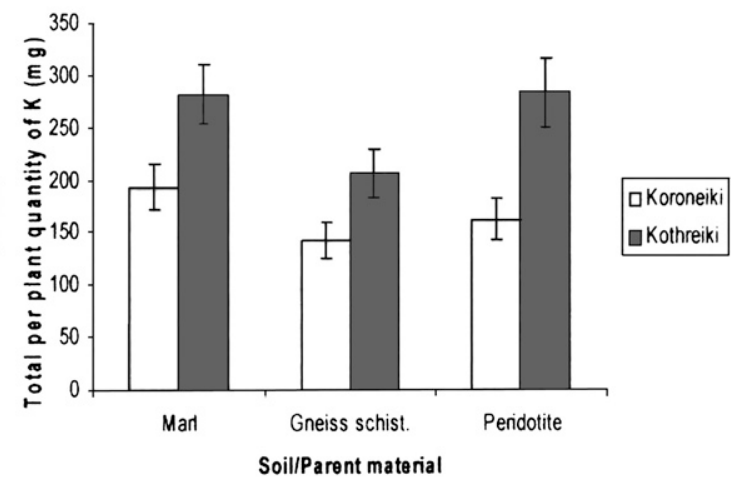

(F)

Fig. 1. Total per plant quantity of manganese (A), iron (B), zinc (C), calcium (D), magnesium (E), and potassium (F) absorbed by the olive cultivars Koroneiki and Kothreiki when each one of them was grown in three soils (from parent material Marl, Gneiss schist., and Peridotite) with different physicochemical properties.

soils. As is obvious from this table, 'Kothreiki' had significantly lower use efficiency of Mn in Marl and Gneiss schist. soils and that of $\mathrm{Fe}$ in all soils compared with the cultivar Koroneiki. In contrast to that, $\mathrm{Zn}$ use efficiency did not differ between the two cultivars studied in each of the three soils. From the same table, it is concluded that irrespective of the soil where the olive plants were grown, $\mathrm{Ca}$ use efficiency and $\mathrm{K}$ use efficiency did not differ between the studied cultivars. Magnesium was more efficiently 
Table 4. Concentrations of manganese $(\mathrm{Mn})$, iron $(\mathrm{Fe})$, zinc $(\mathrm{Zn})$, calcium $(\mathrm{Ca})$, magnesium $(\mathrm{Mg})$, and potassium $(\mathrm{K})$ in the leaves, stems, and roots of the olive cultivars Koroneiki and Kothreiki when each one of them was grown in three soils (from parent material Marl, Gneiss schist., and Peridotite) with different physicochemical properties.

\begin{tabular}{|c|c|c|c|c|c|c|c|c|}
\hline \multirow[b]{2}{*}{ Soil } & \multirow[b]{2}{*}{ Cultivar } & \multirow[b]{2}{*}{ Organs } & $\mathrm{Mn}$ & $\mathrm{Fe}$ & $\mathrm{Zn}$ & $\mathrm{Ca}$ & $\mathrm{Mg}$ & $\mathrm{K}$ \\
\hline & & & \multicolumn{3}{|c|}{$\left(\mu g \cdot g^{-1} D W\right)$} & \multicolumn{3}{|c|}{$(\% \mathrm{DW})$} \\
\hline \multirow[t]{2}{*}{ Marl } & Kor & Leaves & $16 b^{z}$ & $58 \mathrm{a}$ & $12 \mathrm{a}$ & $0.84 \mathrm{~b}$ & $0.08 \mathrm{a}$ & $\overline{0.81 \mathrm{a}}$ \\
\hline & Koth & & $26 \mathrm{a}$ & $62 \mathrm{a}$ & $11 \mathrm{a}$ & $1.08 \mathrm{a}$ & $0.07 \mathrm{a}$ & $0.80 \mathrm{a}$ \\
\hline \multirow[t]{2}{*}{ Gneiss schist. } & Kor & & $12 \mathrm{~b}$ & $57 \mathrm{a}$ & $14 \mathrm{a}$ & $1.03 \mathrm{a}$ & $0.10 \mathrm{a}$ & $1.00 \mathrm{a}$ \\
\hline & Koth & & $19 \mathrm{a}$ & $51 \mathrm{a}$ & $11 \mathrm{a}$ & $0.97 \mathrm{a}$ & $0.06 \mathrm{~b}$ & $0.79 \mathrm{a}$ \\
\hline \multirow[t]{2}{*}{ Peridotite } & Kor & & $21 \mathrm{a}$ & $70 \mathrm{a}$ & $19 \mathrm{a}$ & $0.88 \mathrm{~b}$ & $0.14 \mathrm{a}$ & $0.98 \mathrm{a}$ \\
\hline & Koth & & $26 \mathrm{a}$ & $58 \mathrm{a}$ & $10 \mathrm{~b}$ & $1.06 \mathrm{a}$ & $0.09 \mathrm{~b}$ & $0.96 \mathrm{a}$ \\
\hline \multirow[t]{2}{*}{ Marl } & Kor & Stems & $28 \mathrm{a}$ & $53 \mathrm{a}$ & $9 \mathrm{a}$ & $0.50 \mathrm{a}$ & $0.03 \mathrm{a}$ & $0.43 \mathrm{~b}$ \\
\hline & Koth & & $21 \mathrm{a}$ & $42 \mathrm{a}$ & $7 \mathrm{a}$ & $0.58 \mathrm{a}$ & $0.04 \mathrm{a}$ & $0.55 \mathrm{a}$ \\
\hline \multirow[t]{2}{*}{ Gneiss schist. } & Kor & & $23 \mathrm{a}$ & $54 \mathrm{a}$ & $14 \mathrm{a}$ & $0.55 \mathrm{~b}$ & $0.04 \mathrm{a}$ & $0.34 \mathrm{~b}$ \\
\hline & Koth & & $21 \mathrm{a}$ & $52 \mathrm{a}$ & $10 \mathrm{~b}$ & $0.68 \mathrm{a}$ & $0.04 \mathrm{a}$ & $0.50 \mathrm{a}$ \\
\hline \multirow[t]{2}{*}{ Peridotite } & Kor & & $44 \mathrm{a}$ & $139 a$ & $13 \mathrm{a}$ & $0.56 \mathrm{a}$ & $0.06 \mathrm{a}$ & $0.38 \mathrm{a}$ \\
\hline & Koth & & $23 \mathrm{~b}$ & $48 \mathrm{~b}$ & $8 \mathrm{~b}$ & $0.62 \mathrm{a}$ & $0.05 \mathrm{a}$ & $0.47 \mathrm{a}$ \\
\hline \multirow[t]{2}{*}{ Marl } & Kor & Root & $46 \mathrm{~b}$ & $1590 \mathrm{~b}$ & $19 \mathrm{a}$ & $0.99 \mathrm{a}$ & $0.15 \mathrm{~b}$ & $0.69 \mathrm{a}$ \\
\hline & Koth & & $100 \mathrm{a}$ & $3763 \mathrm{a}$ & $24 \mathrm{a}$ & $0.68 \mathrm{~b}$ & $0.27 \mathrm{a}$ & $0.75 \mathrm{a}$ \\
\hline \multirow[t]{2}{*}{ Gneiss schist. } & Kor & & $34 \mathrm{~b}$ & $1213 \mathrm{~b}$ & $28 \mathrm{a}$ & $0.63 \mathrm{a}$ & $0.19 \mathrm{~b}$ & $0.54 \mathrm{~b}$ \\
\hline & Koth & & 94 a & $4600 \mathrm{a}$ & $31 \mathrm{a}$ & $0.60 \mathrm{a}$ & $0.33 \mathrm{a}$ & $0.59 \mathrm{~b}$ \\
\hline \multirow[t]{2}{*}{ Peridotite } & Kor & & $58 \mathrm{~b}$ & $2350 \mathrm{~b}$ & $19 a$ & $0.64 \mathrm{a}$ & $0.18 \mathrm{~b}$ & $0.43 \mathrm{~b}$ \\
\hline & Koth & & $93 \mathrm{a}$ & $3720 \mathrm{a}$ & $20 \mathrm{a}$ & $0.68 \mathrm{a}$ & $0.35 \mathrm{a}$ & $0.58 \mathrm{a}$ \\
\hline
\end{tabular}

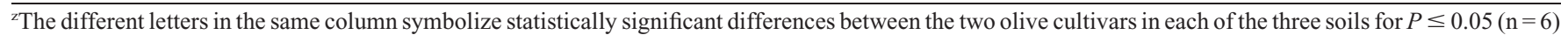
(SPSS, Chicago, IL; $t$ test).

$\mathrm{DW}=$ dry weight.

Table 5. Distribution (\%) of the total per plant quantity of manganese (Mn), iron (Fe), and zinc ( $\mathrm{Zn})$ in the three vegetative tissues (root, stem, and leaves) of the olive cultivars Koroneiki and Kothreiki when each one was grown in three soils (from parent material Marl, Gneiss schist., and Peridotite) with different physicochemical properties.

\begin{tabular}{|c|c|c|c|c|c|}
\hline Soil & Cultivar & Micronutrient & Root & Stem & Leaves \\
\hline \multirow[t]{2}{*}{ Marl } & Kor & $\mathrm{Mn}$ & $50.2 b^{z}$ & $38.0 \mathrm{a}$ & $11.8 \mathrm{a}$ \\
\hline & Koth & & $74.1 \mathrm{a}$ & $12.8 \mathrm{~b}$ & $13.1 \mathrm{a}$ \\
\hline \multirow[t]{2}{*}{ Gneiss schist. } & Kor & & $56.5 \mathrm{~b}$ & $34.2 \mathrm{a}$ & $9.3 \mathrm{a}$ \\
\hline & Koth & & $81.3 \mathrm{a}$ & $10.8 \mathrm{~b}$ & $7.9 \mathrm{a}$ \\
\hline \multirow[t]{2}{*}{ Peridotite } & Kor & & $44.0 \mathrm{~b}$ & $44.0 \mathrm{a}$ & $12.0 \mathrm{a}$ \\
\hline & Koth & & $76.0 \mathrm{a}$ & $12.9 \mathrm{~b}$ & $11.1 \mathrm{a}$ \\
\hline \multirow[t]{2}{*}{ Marl } & Kor & $\mathrm{Fe}$ & $93.7 \mathrm{a}$ & $3.9 \mathrm{a}$ & $2.4 \mathrm{a}$ \\
\hline & Koth & & $98.0 \mathrm{a}$ & $0.9 \mathrm{~b}$ & $1.1 \mathrm{~b}$ \\
\hline \multirow[t]{2}{*}{ Gneiss schist. } & Kor & & $94.0 \mathrm{a}$ & $3.7 \mathrm{a}$ & $2.3 \mathrm{a}$ \\
\hline & Koth & & $98.8 \mathrm{a}$ & $0.6 \mathrm{~b}$ & $0.6 \mathrm{~b}$ \\
\hline \multirow[t]{2}{*}{ Peridotite } & Kor & & $90.8 \mathrm{a}$ & $7.1 \mathrm{a}$ & $2.1 \mathrm{a}$ \\
\hline & Koth & & $98.3 \mathrm{a}$ & $0.8 \mathrm{~b}$ & $0.9 \mathrm{~b}$ \\
\hline \multirow[t]{2}{*}{ Marl } & Kor & $\mathrm{Zn}$ & $49.3 \mathrm{~b}$ & $29.6 \mathrm{a}$ & $21.1 \mathrm{a}$ \\
\hline & Koth & & $64.4 \mathrm{a}$ & $15.6 \mathrm{~b}$ & $20.0 \mathrm{a}$ \\
\hline \multirow[t]{2}{*}{ Gneiss schist. } & Kor & & $59.1 \mathrm{~b}$ & $26.7 \mathrm{a}$ & $14.2 \mathrm{a}$ \\
\hline & Koth & & $73.7 \mathrm{a}$ & $14.3 \mathrm{~b}$ & $12.0 \mathrm{a}$ \\
\hline \multirow[t]{2}{*}{ Peridotite } & Kor & & $37.3 \mathrm{~b}$ & $33.9 \mathrm{a}$ & $28.8 \mathrm{a}$ \\
\hline & Koth & & $65.3 \mathrm{a}$ & $18.0 \mathrm{~b}$ & $16.7 \mathrm{~b}$ \\
\hline
\end{tabular}

${ }^{z}$ The different letters in the same column symbolize statistically significant differences between the two olive cultivars in each of the three soils for $P \leq 0.05(\mathrm{n}=6)$ (SPSS, Chicago, IL; $t$ test).

used by 'Koroneiki’ than by 'Kothreiki’ in all soils.

\section{Discussion}

According to Alifragis and Papamichos (1995), the concentrations of Mn, Fe, and Zn determined in the three soils, with the DTPA method, were moderate to sufficient. The $\mathrm{pH}$ of the soil from parent material Gneiss schist. was almost neutral, whereas that of the other two soils (from parent material Marl and Peridotite) was slightly alkaline (Table 1). Generally, when the $\mathrm{pH}$ is alkaline, the nonavailable (oxides) forms of $\mathrm{Mn}$ and $\mathrm{Fe}$ are present in the soils. However, $\mathrm{pH}$ values did not reduce significantly $\mathrm{Mn}$ and Fe levels in the leaves, because their levels were greater than 12 and $50 \mu \mathrm{g} \cdot \mathrm{g}^{-1} \mathrm{DW}$ for $\mathrm{Mn}$ and $\mathrm{Fe}$, respectively (Table 4). Concentrations greater than $20 \mu \mathrm{g} \cdot \mathrm{g}^{-1} \mathrm{DW}$ for $\mathrm{Mn}$ and in the range between 50 and $150 \mu \mathrm{g} \cdot \mathrm{g}^{-1} \mathrm{DW}$ for Fe are referred by Panagiotopoulos (2001) as sufficient ones, whereas in the range between 5 and $20 \mu \mathrm{g} \cdot \mathrm{g}^{-1} \mathrm{DW}$ for Mn was relatively deficient. It should be pointed out that under alkaline $\mathrm{pH}$ conditions, $\mathrm{Mn}$ and $\mathrm{Fe}$ complexes with organic matter constitute $80 \%$ to $95 \%$ of the total soluble $\mathrm{Mn}$ and $\mathrm{Fe}$. The stability of these complexes increases with the increase of soil $\mathrm{pH}$. Therefore, alkaline $\mathrm{pH}$ does not necessarily imply $\mathrm{Mn}$ and $\mathrm{Fe}$ deficiency of plants (Keramidas, 1997). This is what probably happened in the Peridotite soil. Indeed, the concentrations of $\mathrm{Mn}$ (greater than $20 \mu \mathrm{g} \cdot \mathrm{g}^{-1} \mathrm{DW}$ ) and Fe (greater $50 \mu \mathrm{g} \cdot \mathrm{g}^{-1} \mathrm{DW}$ ) were sufficient in the leaves of both olive cultivars when grown in the Peridotite soil. The $\mathrm{CaCO}_{3}$ content (\%) of the Peridotite soil was much higher compared with those of the Gneiss schist. and Marl (Table 1). However, the effect of the high $\mathrm{CaCO}_{3}$ content in the case of the Peridotite soil was not inhibitory for $\mathrm{Fe}$ and $\mathrm{Mn}$ absorption by olive plants. Generally, the most appropriate soils for growth and fruiting of olive trees are the SL after sufficient fertilization with $\mathrm{N}, \mathrm{K}$, and $\mathrm{P}$ and with adequate water content (Therios, 2005). In our case, although the Gneiss schist. soil was a SL one, plant growth was less than in the other two soils (from parent material Marl and Peridotite). This happened probably as a result of the lower $(\%)$ organic matter content and CEC (only $17 \%$ compared with those of $43 \%$ and $48 \%$ of Marl and Peridotite soils, respectively) and water-holding capacity ( $22 \%$, compared with those of $29 \%$ and $30 \%$ of Marl and Peridotite soils) than those of the other two soils.

In all the soils, both cultivars had the greatest part of total $\mathrm{Mn}$ distributed in their root system. 'Kothreiki' had a greater percentage of the total root Mn content distributed in the root system $(74 \%$ to $80 \%)$ than 'Koroneiki' (44\% to 56\%) (Table 5). That high ability of 'Kothreiki' to accumulate Mn in its root system could be possibly advantageous in soils with high $\mathrm{Mn}$ concentrations and could constitute a detoxification mechanism to olive trees, protecting the aboveground part of the tree from Mn toxicity. Under Mn excess/toxicity conditions also, other plant species such as Mentha spicata, Citrus sp., Pseudoaccacia sp., Juglans regia, Populus sp. and Eucalyptus sp. accumulate most of the total Mn absorbed in the root system to protect their shoots from Mn toxicity (Asrar et al., 2005; Chatzistathis and Alifragis, 2004; Loneragan, 1988; Papadakis, 2004). It should be pointed out that the same tendency of high Mn accumulation in the root system of 'Kothreiki' was also observed in our previous hydroponic experiments testing a great range of $\mathrm{Mn}$ concentrations 
Table 6. Nutrient use efficiency (mg of the total plant DW/ $\mu$ g of the total per plant quantity of micronutrient or mg of the total per plant quantity of macronutrient) of the olive cultivars Koroneiki and Kothreiki when each of them was grown in three soils (from parent material Marl, Gneiss schist., and Peridotite) with different physicochemical properties.

\begin{tabular}{|c|c|c|c|c|c|c|c|}
\hline \multirow[b]{2}{*}{ Soil } & \multirow[b]{2}{*}{ Cultivar } & Mn UE & Fe UE & $\mathrm{Zn} \mathrm{UE}$ & $\mathrm{Ca} \mathrm{UE}$ & Mg UE & K UE \\
\hline & & \multicolumn{3}{|c|}{$\begin{array}{l}\text { (mg of the total plant } \mathrm{DW} / \mu \mathrm{g} \text { of the total } \\
\text { per plant quantity of micronutrient) }\end{array}$} & \multicolumn{3}{|c|}{$\begin{array}{l}\text { (mg of the total plant } \mathrm{DW} / \mathrm{mg} \text { of the total } \\
\text { per plant quantity of macronutrient) }\end{array}$} \\
\hline \multirow[t]{2}{*}{ Marl } & Kor & $31.85 \mathrm{a}^{\mathrm{z}}$ & $1.73 \mathrm{a}$ & $77.53 \mathrm{a}$ & $134.18 \mathrm{a}$ & $1180.31 \mathrm{a}$ & $164.95 \mathrm{a}$ \\
\hline & Koth & $18.68 \mathrm{~b}$ & $0.65 \mathrm{~b}$ & $68.08 \mathrm{a}$ & $132.75 \mathrm{a}$ & $716.61 \mathrm{~b}$ & $143.69 \mathrm{a}$ \\
\hline \multirow[t]{2}{*}{ Gneiss schist. } & Kor & $39.87 \mathrm{a}$ & $1.84 \mathrm{a}$ & $51.04 \mathrm{a}$ & $146.97 \mathrm{a}$ & $878.05 \mathrm{a}$ & $179.51 \mathrm{a}$ \\
\hline & Koth & $17.94 \mathrm{~b}$ & $0.44 \mathrm{~b}$ & $49.15 \mathrm{a}$ & $141.64 \mathrm{a}$ & $534.31 \mathrm{~b}$ & $164.34 \mathrm{a}$ \\
\hline \multirow[t]{2}{*}{ Peridotite } & Kor & $23.33 \mathrm{a}$ & $1.19 \mathrm{a}$ & $61.75 \mathrm{a}$ & $150.23 \mathrm{a}$ & $849.40 \mathrm{a}$ & $183.32 \mathrm{a}$ \\
\hline & Koth & $18.00 \mathrm{a}$ & $0.58 \mathrm{~b}$ & $72.88 \mathrm{a}$ & $133.20 \mathrm{a}$ & $515.50 \mathrm{~b}$ & $157.47 \mathrm{a}$ \\
\hline
\end{tabular}

zThe different letters in the same column symbolize statistically significant differences between the two cultivars in each of the three soils for $P \leq 0.05$ ( $\mathrm{n}=6$ ) (SPSS, Chicago, IL; $t$ test).

$\mathrm{DW}=$ dry weight; $\mathrm{Mn}=$ manganese; $\mathrm{UE}=$ use efficiency; $\mathrm{Fe}=$ iron; $\mathrm{Zn}=$ zinc; $\mathrm{Ca}=$ calcium; $\mathrm{Mg}=$ magnesium; $\mathrm{K}=$ potassium.

(from 0 to $640 \mu \mathrm{M}$ ) in the nutrient solution (Chatzistathis, unpublished data). Differences between genotypes of the same species in growth, absorption, and distribution of $\mathrm{Mn}$ within tissues have been also reported by researchers in other species such as soybean, Triticales, and Pseudotsuga menziesii (Ducic et al., 2006; Heenan and Carter, 1976; Quartin et al., 2001) and are in accordance with our results.

Considering the distribution of Fe between root system and shoot, the greater part of it accumulated in the root system (greater than $95 \%$ of the total per plant content). A similar trend was recorded for $\mathrm{Zn}$ (but the percentage distributed in the root system was much less than 95\%) (Table 5). Although 'Kothreiki' absorbed significantly greater quantities of $\mathrm{Fe}$ and $\mathrm{Zn}$ compared with 'Koroneiki', the concentrations of $\mathrm{Fe}$ and $\mathrm{Zn}$ in its leaves were, in almost all cases, not greater than those of 'Koroneiki' (Table 4). This probably happened because a much greater percentage of the total per plant $\mathrm{Fe}$ and $\mathrm{Zn}$ content was retained in the root system of 'Kothreiki' (Table 5). Therefore, the root system exerts a buffering role controlling Fe and $\mathrm{Zn}$ levels in the top of the tree. Calcium and potassium were equally distributed in roots, stems, and leaves in both olive cultivars and in al soils, whereas $\mathrm{Mg}$ was mainly distributed in the root system (data not shown). Furthermore, the concentrations of all nutrient elements in the leaves of both olive cultivars were in the normal range, with the exception of Mn concentration in the leaves of 'Koroneiki', when cultivated in the Gneiss schist. and Marl soils (12 and $16 \mu \mathrm{g} \cdot \mathrm{g}^{-1} \mathrm{DW}$, less than $20 \mu \mathrm{g} \cdot \mathrm{g}^{-1}$ DW) (Table 4), which could be characterized as relatively, but not seriously, deficient according to Panagiotopoulos (2001).

The examined cultivars accumulated different amounts of micronutrients (Fig. 1). However, cultivar Kothreiki, which accumulated more $\mathrm{Mn}$ and $\mathrm{Fe}$, had significantly lower use efficiency of $\mathrm{Mn}$ in Marl and Gneiss schist. soils and that of $\mathrm{Fe}$ in all soils compared with 'Koroneiki', whereas Zn use efficiency did not significantly differ between the two cultivars in each of the three soils (Table 6). Although 'Kothreiki' absorbed and accumulated significantly greater quantities of $\mathrm{Mn}$ and $\mathrm{Fe}$ in all soils compared with 'Koroneiki', the increase of its total plant biomass was not so sufficient to benefit from the greater total uptake of these two elements. The "retention" of a great part of the total per plant content of Mn and Fe in the root system and the limited transport to the shoot means that 'Kothreiki' had lower use efficiency of $\mathrm{Mn}$ and Fe compared with 'Koroneiki'. Jiang (2006) and Jiang and Ireland (2005) state that Mn efficient wheat cultivars own this ability to a better internal use of $\mathrm{Mn}$ rather than to a higher plant Mn accumulation. Based on that remark of the mentioned researchers, it could be concluded that 'Kothreiki' is not probably well adapted in Mn-deficient soils. According to Rengel (2001), who conducted a review on genotypic differences in micronutrient use efficiency of many crops, micronutrient-efficient genotypes were capable of increasing the available soil micronutrient pools through changing chemical and microbiological properties of the rhizosphere as well as by growing thinner and longer roots and by having more efficient uptake and transport mechanisms. In our case, 'Koroneiki' could be considered as a Mn- and Fe-efficient one compared with 'Kothreiki' because of its better transport system of these two elements from the root to the shoot. According to Maruyama et al. (2005), who conducted a comparison of iron availability in leaves of barley and rice, the difference in the $\mathrm{Fe}$ acquisition ability between these two species was affected by the differential mugineic acid secretion. Maybe a similar mechanism is working in the two olive cultivars studied. In all soils, Ca use efficiency and $\mathrm{K}$ use efficiency did not significantly differ between the studied cultivars (Table 6). In contrast to that, Damon and Rengel (2007) and Rengel and Damon (2008), who studied the $\mathrm{K}$ efficiency in different wheat genotypes under glasshouse and field conditions, and different crops, respectively, found that this efficiency differed between crops or genotypes of the same species.

\section{Literature Cited}

Alifragis, D.A. and N. Papamichos. 1995. Soil sampling and chemical analyses of forest soils and vegetative tissues [in Greek]. Dedousi Publications, Thessaloniki, Greece.

Allison, L.E. 1965. Organic matter, p. 1367-1378. In: Black, C.A. (ed.). Methods of soil analysis. Vol. 2. Am. Soc. Agron. Inc. Publ., Madison, WI.
Asrar, Z., R.A. Khavari-Nejad, and H. Heidari. 2005. Excess manganese effects on pigments of Mentha spicata at flowering stage. Arch. Agron. Soil Sci. 51:101-107.

Bates, R.G. 1964. Determination of pH. Theory and practice. John Wiley and Sons, New York, NY.

Bower, C.A., R.F. Reitemeier, and M. Firemann. 1952. Exchangeable cation analysis of saline and alkali soils. Soil Sci. 73:251-261.

Chapin, F.S. and K. Van Cleve. 1991. Approaches to studying nutrient uptake, use and loss in plants, p. 185-207. In: Pearcy, R.W., J.R. Ehleringer, H.A. Mooney, and P.W. Rundel (eds.). Plant physiological ecology—Field methods and instrumentation. Chapman and Hall, New York, NY.

Chatzistathis, Th. and D. Alifragis. 2004. The influence of soil liming on the limitation of $\mathrm{Mn}$ and $\mathrm{Cu}$ toxicity, in Populus, Pseudoacacia, Junglans and Eucalyptus plantations [in Greek], p. 465-478. Proc. 10th Panhellenic Soil Science Symposium, Volos, Greece, 22 25 Sept. 2004.

Damon, P.M. and Z. Rengel. 2007. Wheat genotypes differ in potassium efficiency under glasshouse and field conditions. Aust. J. Agr. Res. 58:816-825.

Ducic, T., L. Leinemann, R. Finkeldey, and A. Polle. 2006. Uptake and translocation of manganese in seedlings of two varieties of douglas fir (Pseudotsuga menziesii var. viridis and glauca). New Phytol. 170:11-20.

El-Jaoual, T. and D.A. Cox. 1998. Manganese toxicity in plants. J. Plant Nutr. 21:353-386.

Heenan, D.P. and O.G. Carter. 1976. Tolerance of soybean cultivars to manganese toxicity. Crop Sci. 16:389-391.

Jiang, W.Z. 2006. Mn use efficiency in different wheat cultivars. Environ. Exp. Bot. 57:41-50.

Jiang, W.Z. 2008. Comparison of responses to Mn deficiency between the UK wheat genotypes Maris Butler, Paragon and the Australian wheat genotype C8MM. J. Integr. Plant Biol. 50:457465.

Jiang, W.Z. and C.R. Ireland. 2005. Characterization of manganese use efficiency in UK wheat cultivars grown in a solution culture system and in the field. J. Agr. Sci. 143:151-160.

Keramidas, B. 1997. Fertility of soils [in Greek]. Aristotle University of Thessaloniki, Thessaloniki, Greece, p. 73-74.

Klute, M. 1986. Method of soil analysis. Part IPhysical and mineralogical methods, p. 404-408. In: Klute, A. (ed.). Agron. Monograph No. 9. ASA, CSSA and SSSA, Madison, WI.

Loneragan, J.F. 1988. Distribution and movement of manganese in plants, p. 113-124. In: Graham, R.D., R.J. Hannam, and N.C. Uren (eds.). Manganese in soils and plants. Proc. of the International symposium on 'Manganese in soils and 
plants'. Kluwer Academic Publishers, Dordrecht, The Netherlands.

Maruyama, T., K. Higuchi, M. Yoshida, and T. Tadano. 2005. Comparison of iron availability in leaves of barley and rice. Soil Sci. Plant Nutr. 51:1037-1042.

Panagiotopoulos, L. 2001. Mineral nutritionFertilization of olive trees [in Greek]. Agriculture and Cattle-raising 3:36-44.

Papadakis, I.E. 2004. Reaction of Citrus trees to manganese [in Greek]. Doctoral dissertation.
Aristotle University of Thessaloniki, Thessaloniki, Greece.

Quartin, V.M.L., M.L. Antunes, M.C. Muralha, M.M. Sousa, and M.A. Nunes. 2001. Mineral imbalance due to manganese excess in triticales. J. Plant Nutr. 24:175-189.

Rengel, Z. 2001. Genotypic differences in micronutrient use efficiency in crops. Commun. Soil Sci. Plant Anal. 32:1163-1186.

Rengel, Z. and P.M. Damon. 2008. Crops and genotypes differ in efficiency of potassium uptake and use. Physiol. Plant. 133:624-636.
Shuxin, T.U., S. Jinghe, G. Zhifen, H. Ming, and Z. Ping. 2000. Genotypic variations in potassium absorption and utilization by amaranthus spp. Pedosphere 10:363-

372.

Soil Taxonomy. 1975. A basic system of soil classification for making and interpreting soil surveys. 1st ed U.S. Department of Agriculture's Soil Survey Staff.

Therios, I. 2005. Oliveculture [in Greek]. Gartaganis Publications, Thessaloniki, Greece. p. 127. 